\author{
Anna GRZEŚ, PhD \\ Institute of Management, University of Bialystok \\ e-mail: agrzes@uwb.edu.pl \\ ORCID: 0000-0002-4634-172X
}

DOI: $10.15290 /$ oes.2019.04.98.04

\title{
THE MEASUREMENT OF LABOUR PRODUCTIVITY IN THE ENTERPRISE SECTOR. THE EXAMPLE OF POLAND ${ }^{1}$
}

\begin{abstract}
Summary
Purpose - The aim of this paper is to present the indicators of labour productivity and dilemmas related to their interpretation. The paper examines the level of this phenomenon in the enterprise sector within the Polish economy.

Research method - The measurement of labour productivity in the enterprise sector will be made using the indicators calculated on the basis of available data from the national statistics of the Central Statistical Office in the years 2005-2017 and the unpublished data from the years 2005-2013.

Results - The theoretical considerations on labour productivity have shown that a set of available indicators should be used and complemented with the index of technical equipment. The labour productivity in the enterprise sector was varied. In the years 2005-2017 it grew quite dynamically until 2013, however after this year it clearly decreased. Since 2014 there has been a more rapid increase in the labour costs (including wages) than in terms of the labour productivity.

Implications / originality / value - The majority of the previous research available focuses on one of the measures of labour productivity, which is the relation of sales revenue (or gross added value) to the number of employees. The paper includes those indicators that contributed to an ambiguously positive image of the studied phenomenon and confirmed the legitimacy of using at least several different measures. In addition, this productivity was tested at the level of the PKD 2007 sections
\end{abstract}

Key words: labour productivity, employment, labour cost, enterprise sector, Poland

JEL Classification: J24, J21, J30, L70, L80

\section{Introduction}

The improvement of labour productivity constitutes one of the essential issues which are becoming the subject of interest to enterprises, together with the increasing pressure on wage increases, progressive globalization and the development of the knowledge-based economy. It is defined as the effects achieved by labour resources (e.g. real output) divided by the outlays made by the resources

\footnotetext{
1 Article received on 9 April 2019, accepted on 9 September 2019.
} 
(e.g. total employed persons) and constitutes one of the elements of economic effectiveness. In the macroeconomic scale, the increase of labour productivity contributes to the increase of the gross domestic product and also to the social welfare [comp. among others: Balk, 2014, pp. 35-43]. At the level of an enterprise, any noticeable changes in levels ought to be the subject of interest for group management in order that it becomes clear on how to improve the organization of work, modify employee reward strategies and ultimately understand, the strategies required to increase the profits of an enterprise.

The increase of labour productivity is a positive phenomenon which indicates the improvement in the way labour resources available within an enterprise are being utilised. An increase in the economic benefits will also create the possibility of increasing employee remuneration. However, there still exist a number of questions on how to most effectively and accurately measure and interpret the category of labour productivity and establish which indicators among those available should be used in a particular situation, especially taking into consideration the fact that depending on the level of reflections (i.e. micro, meso or macro) various indicators are used, what factors may decide upon its level? The research on the level of labour productivity in the sector of enterprises in Poland has shown that in the years 20052013 there was an increase in the labour productivity measured using the gross added value per one employee in all types of manufacturing and services isolated in accordance with the Eurostat classification. However, the level and dynamics of this measure significantly differed [Grześ, 2017, pp. 249-274].

Some practitioners have observed that in a competitive surrounding the traditional economic perception of the category of productivity may mislead the decision-makers and shift their activities at reducing the costs of the operational activity at the cost of creating value [Sunderland, Kane, 1996, pp. 57-76]. However, although such a view may appear to be justified, this is difficult to implement in practice due to insufficient adjustment of the categories typical for financial reports to such recognition of labour productivity and owing to the relatively high aggregation of necessary data even at the level of an enterprise.

Taking into consideration the limitations in access to quality data in order to assess the level of labour productivity, the Author adopted the traditional economic approach based on the categories present in financial reports and publicly available statistics. The aim of the paper is to present the indicators of labour productivity and the dilemmas connected with their interpretation and subsequently to analyze and evaluate the scale of this phenomenon in the sector of enterprises in Poland that were analyzed in the cross section PKD 2007.

The measurement includes data obtained from national statistics during the period 2005-2017. 


\section{The approaches to the measurement of labour productivity}

Productivity is one of the key indicators of economic growth and competitiveness of enterprises and the economy [Porter, 1990]. The measurement of labour productivity was the subject of interest for Sargant Florence [1920] who understood it as the quantity of identical products made per one working hour. For the measurement of labour productivity the Bureau of Labor Statistics (BLS) still uses a traditional indicator being the output per hour relation. This indicator was first published in 1959. The value of production was set by the real gross national product in the business sector, with the exception of the agricultural sector, whereas the value of the labour input - by one of the categories such as: employment, the average weekly working time, the remuneration for one working hour and the labour cost [comp. Handbook of..., 2012, pp. 89-98].

The phenomenon of productivity is also the subject of interest of the OECD that customarily defines it as the relation between the volume of output and the volume of input [OECD Compendium..., 2018]. OECD analysts divide the total factor productivity (TFP) into partial productivities. One of them is labour productivity that takes into consideration the labour input. The basic indicator that is used for its measurement at the level of the economy of a particular country is the gross domestic product per hour worked. The outlays of labour resources are considered as the total worked hours by all employees involved in the production as the number of worked hours more appropriately (according to the researchers) reflects its level rather than the number of employees. However, they notice that it is not a complete measure of labour input as it fails to take into consideration the changes in the skills acquired by employees attributed to improving their education or gaining new occupational experience. Undoubtedly, these changes affect the production volume. The level of labour productivity to a large degree depends on the usage of other production factors (i.e. capital, indirect inputs, both technical and organizational changes and economies of scale) [OECD Compendium ..., 2018].

We can observe quite clear diversity in terms of labour productivity between the types of economic activity in Poland and similar activities in other countries. Its level is affected by the intensity of using resources: labour using various qualifications and competences, physical capital and know-how for the creation of the volume of production as well as the scope of product and process innovations, the economies of scale, international competition and the degree of product standardization. In accordance with the OECD methodology in most countries at the level of sections or departments (with the exception of the sections connected with the agricultural sector or public administration) labour productivity is measured using the following relation: the gross added value (in fixed prices) per one worked hour. In some countries (Japan, Korea, Latvia, Mexico and USA) the labour input signifies the total number of employees because of the lack of data regarding the working time [OECD Compendium..., 2018].

One may observe divergences in the Polish literature relating to the perception of labour productivity. It is associated with the efficiency or it is understood 
adversely [comp. Sierpińska, Jachna, 2012; Analiza ekonomiczna, 2013, p. 265]. Kwiatkowski uses the quantity approach by defining labour efficiency as the relation between the production volume and the average number of employees. Additionally, the Author has observed an important issue: the fact that production increase results from the technological progress when the level of labour resources input remains at the same level [Podstany ekonomii, 2012, p. 202]. Gableta [Potencjat pracy..., 1998, p. 15] and Kosieradzka [2012, pp. 19-21] define productivity as: "the relation between the volume of production made and sold in a certain time period and the amount (value) of used and/or used up input resources". Gableta emphasizes that productivity is frequently associated with efficiency and both concepts may be expressed using the same meters. However, the scientist has also observed that these concepts differ as efficiency denotes "the feature of the object (e.g. an employee, a machine) taking part in the production process. Meanwhile, it does not really matter whether the demand for the produced goods is external or domestic. The basic category of the efficiency indicator in the numerator is the volume of output" [Potencjat pracy..., 2006, p. 207]. While the finished products are at the disposal of an enterprise, it does not generate cash that enable the purchase of raw materials, materials and services necessary for further production. Therefore, if the efficiency increases and productivity decreases owing to the decline in both demand and the revenue connected with it, it results in an increase of stocks of finished products and this becomes detrimental for the enterprise. In a longer time perspective the enterprise will be forced to reduce both production and costs, including the cost of labour resources by either dismissing its employees or by reducing their salaries (provided that the employees accept such a solution). The abandonment of such operations (among others) as a consequence leads to a deterioration in the financial results and will decelerate any further growth.

\section{The meters of labour productivity in enterprises. The dilemmas connected with the selection of an indicator and its interpretation}

The availability of valuable and personal data sets the traditional approach to the measurement of labour productivity. From the perspective of an enterprise with diversified production assortment, the effects include such valuable data as: the net sales revenue or the gross value added, while labour input is the average number of individuals employed (or alternatively the number of working people) per full time contacts; the effective (or nominal) working time or the labour costs. The diversity of the aforementioned categories contributes to the fact that it is possible to use six different productivity indicators divided into the following two groups:

- the first one being the relation between the sales revenue and one of the aforementioned labour inputs;

- the second one being the relation between the added value and one of the aforementioned labour inputs. 
These indicators provide information among others on what is the sales revenue / added value per one employee in a certain time unit or what the labour cost is. The higher the values of these indicators in a certain period are, the more productive the labour resources will be. The interpretation gives one view of the rate of change in the level of labour productivity.

Since as many as six indicators may specify labour productivity a number of dilemmas arise relating to both the selection of the most appropriate and reliable meter and the categories shaping its level. During the selection of a particular indicator one usually draws attention to the simplicity of calculating it and to the accessibility of data that may be used. At the level of an enterprise, the degree of data specificity is high because, theoretically it may generate all of the possible data. However, in practice, the availability and application of the data may encounter problems due to it being collected in accordance with the existing rules of financial reporting which, in turn, provides data that is to a large degree general and does not entirely reflect the dimensions of the phenomenon.

The simplest way is to calculate those productivity indicators that are based on the revenue from the sale of products, goods and services because of the accessibility of data. However, they are characterized by a considerable level of generalization as the category of sales revenue is the resultant of the amount of goods and services sold and their price. Price reduction in the situation of a similar level of sales volume in the short term will reduce labour productivity, however over a longer period of time it may increase the demand for goods and services and consequently could contribute to the increase of labour productivity. Such a tendency can occur when the price of goods remain at a level which will encourage people to make purchases and will result in the larger dynamics of growth of sales revenue in the situation of lower dynamics of employment growth or will lead to the maintenance of the non-employment rate growth (which may occur as the result of modernizing the technologies of production or improving the organization of work). Therefore, by applying the category of sales revenue to make calculations, it is necessary to specify the reasons for changes in its value and take these into consideration during the interpretation of the indicator of labour productivity.

Sales revenue as the effect of economic activity are formed as the result of using all of the outlays that are either directly or indirectly connected with the enterprise. The outlays that are directly connected with the entity (i.e. are not produced by the enterprise by itself, but are purchased) require only the involvement of labour resources to obtain them for further production. It means that in the situation of continuously more frequent outsourcing of materials and services, the gross added value is becoming a more meaningful category of effects, the formation of which is directly dependent on the usage of labour resources. Nevertheless, this category requires the acquisition of a more comprehensive set of data and an awareness of the manner of calculation in comparison with sales revenue from the sale of products, goods and materials (the basic data occurring in the income statement). With the exception of the net financial result, one of the basic elements of added value are non-material costs including chiefly the labour costs. The main component 
of such costs are employee salaries that perform the motivational function. Higher wages enable an employer to motivate their workforce to be more efficient and involved in duties performed at work and as a result labour productivity should increase.

The level of labour productivity is also affected by capital equipment which allows enterprises to prepare more goods at the same time. This relation is the result of the Cobb-Douglas production function with two production factors (capital input $-\mathrm{K}$ and labour input $-\mathrm{L}$ ), with fixed effects of production scale expressed using the formula: $Q_{t}=A_{t} L_{t}{ }^{1-\beta} K^{\beta}$. After its transformation there is formed a function of labour productivity: $\frac{\mathrm{Qt}}{\mathrm{Lt}}=\mathrm{A}_{\mathrm{t}}\left(\frac{\mathrm{Kt}}{\mathrm{Lt}}\right)^{\beta}$, whereas in the logarithmic form: $\ln \frac{\mathrm{Q}}{\mathrm{L}}=\ln \mathrm{A}+\beta \ln \frac{\mathrm{K}}{\mathrm{L}}$ [comp. Solow, 1967, p. 45], where:

$\mathrm{Q}_{\mathrm{t}}$ - total production of all goods in fixed prices in $\mathrm{t}$;

$K_{t}$ - capital input in $t$ (the value of fixed assets in fixed prices in $t$ );

$\mathrm{L}_{\mathrm{t}}-$ the number of employees or hours worked in t;

$\beta-1$ and $\beta$ - the output elasticities of capital and labor, respectively;

$A_{t}=e^{t}-$ the total factor productivity expressing technical progress in $t$;

$\mathrm{Q}_{\mathrm{t}} / \mathrm{L}_{\mathrm{t}}-$ labour productivity in $\mathrm{t}$;

$\mathrm{K}_{\mathrm{t}} / \mathrm{L}_{\mathrm{t}}$ - capital (technical) equipment in $\mathrm{t}$;

Moreover, the level of labour productivity is affected by the category of outlays, which can be expressed using one of three categories. Not without reason the selection of one of them or the calculation of all the meters and the comparison of them will remain. Each category of the labour inputs provides slightly different information. The number of employees with a full-time contract provides data on the volume of labour resources being involved, without the specification of their qualifications and competences. Hours worked are evidence of the involvement of employed individuals in the work processes and also denotes the possible stoppages caused by the failure s of machines, devices or systems. Meanwhile the changes in the labour costs, which constitute the derivative of the wage and the number of employed persons, to a certain extent reflect the level of qualifications, skills, motivation for the work or the situation on the labour market.

The value of labour input is also affected by other factors (such as: the modernization of the fixed assets, the effect of which will be the increase of capital equipment, the improvement of the work organization or specialization of activity) that will result in the changes of the employment structure and working costs. These factors also lead to the increase in labour productivity which, in turn, determines the increase of wages. In economic and psychological terms it appears to be justified to increase them when the dynamics of labour productivity is larger than the dynamics of increase in the sales revenue [Grześ, 2017]. The increase of sales volume requires an increase in employment within enterprises in the short time. However, in recent times wages have begun to increase faster than labour productivity owing to the scarcity of employees (especially specialists). As a consequence of the increase of 
labour costs (the basic element having impact on the price of the produced goods and services) entrepreneurs decide to increase prices (at a similar level to competitors) and at the same time seek ways to replace parts of labour resources with other technological and organizational solutions in order to maintain the profitability of the activity carried out at least at the assumed minimum level.

To sum up, in order to depict the image of labour productivity it becomes necessary to use several indicators that take into consideration mostly various categories of outlays. An essential complementation of these indicators is technical labour equipment, which appears to be useful for the explanation of the reduction in the employment level or the increase of labour productivity without the increase of employment and is simple to calculate on the basis of available financial and personal data. The Author is aware of the fact that it is not the only factor that explains the employment reduction or the increase of labour productivity. Such factors include among others: improved organization of work, the increase of work intensity, more efficient usage of hours worked etc.

\section{The measurement and evaluation of the labour productivity level in the enterprise sector in Poland in the years 2005-2017}

In order to measure labour productivity in the enterprise sector at the level of PKD 2007 section, meters that constitute the relation of revenue from the sale of products, services, materials and goods to the three basic categories of labour resources inputs, (i.e. employment, hours worked and the annual labour costs) will be used. The selection of meters was dictated by the accessibility and manner of collecting data from the national statistics of Statistics Poland (GUS) on the basis of statistic reports F-01 and Z-06 submitted by enterprises and comprising the years 2005-2017. Due to the absence of some data in the available statistics it was impossible to calculate the value of the gross added value for PKD in 2017. Although theoretically the gross added value reflects labour productivity, it was determined for the years 2005-2016.

During the calculation of the indicators of labour productivity the Author used both the categories connected with value (i.e.: sales revenue $(\mathrm{S})$, the annual labour costs (Lc), the gross added value (VA), fixed assets (FA)) and with the quantity (the number of employed people $(\mathrm{L})$, the hours worked $(\mathrm{T})$ ). Owing to the fact that the first among the categories are shown in the current prices, they were realigned using the indexes of prices matching a certain type of activity [www 1]. The level of labour productivity in the enterprise sector is presented in table 1. 
TABLE 1

The indicators of labour productivity and capital equipment (FA/L) in the enterprise sector (fixed prices, the previous year $=100$ ) and their compound annual growth rate (CAGR) between the years 2005 and 2017

\begin{tabular}{|l|c|c|c|c|c|c|c|}
\hline Years & $\begin{array}{c}\text { S/Z in } \\
\text { thousands } \\
\text { of PLN } \\
\text { per 1 } \\
\text { employed } \\
\text { person }\end{array}$ & $\begin{array}{c}\text { S/T in } \\
\text { thousands } \\
\text { of PLN } \\
\text { per hour }\end{array}$ & S/Lc & $\begin{array}{c}\text { AT/Z in } \\
\text { thousands } \\
\text { of PLN per } \\
\text { 1 employed } \\
\text { person }\end{array}$ & $\begin{array}{c}\text { VA/Z in } \\
\text { thousands of } \\
\text { PLN per 1 } \\
\text { employed } \\
\text { person }\end{array}$ & $\begin{array}{c}\text { VA/ T in } \\
\text { thousands } \\
\text { of PLN } \\
\text { per hour }\end{array}$ & VA/Lc \\
\hline 2005 & 369.9 & 183.2 & 9.25 & 182.6 & 85.0 & 42.1 & 2.13 \\
\hline 2006 & 397.7 & 199.6 & 9.57 & 183.8 & 89.6 & 45.0 & 2.16 \\
\hline 2007 & 422.3 & 215.9 & 9.48 & 201.8 & 95.5 & 48.8 & 2.14 \\
\hline 2008 & 439.6 & 226.0 & 9.09 & 212.0 & 97.9 & 50.3 & 2.02 \\
\hline 2009 & 452.5 & 232.9 & 8.98 & 229.6 & 103.3 & 53.2 & 2.05 \\
\hline 2010 & 488.3 & 246.2 & 9.19 & 245.0 & 108.5 & 54.7 & 2.04 \\
\hline 2011 & 538.7 & 263.8 & 9.70 & 256.9 & 115.9 & 56.7 & 2.09 \\
\hline 2012 & 563.1 & 209.5 & 9.57 & 277.6 & 117.6 & 57.6 & 2.00 \\
\hline 2013 & 589.4 & 290.5 & 9.46 & 323.4 & 126.8 & 62.5 & 2.04 \\
\hline 2014 & 510.7 & 289.3 & 8.94 & 276.4 & 139.7 & 79.2 & 2.45 \\
\hline 2015 & 527.1 & 299.0 & 8.84 & 292.9 & 144.2 & 81.8 & 2.42 \\
\hline 2016 & 528.0 & 299.8 & 8.58 & 292.1 & 146.2 & 83.0 & 2.37 \\
\hline 2017 & 530.2 & 302.0 & 8.48 & 284.3 & 142.8 & 81.3 & 2.28 \\
\hline CAGR & 3.0 & 4.3 & -0.7 & 3.8 & 4.4 & 5.6 & 0.6 \\
\hline in \% & & & & & & & \\
\hline
\end{tabular}

Source: own elaboration on the basis: [Zatrudnienie..., 2018; Wyniki finansowe..., 2018; unpublished data from GUS].

The values of indicators presented in table 1 show that enterprises in Poland experienced a considerable increase of labour productivity measured using sales revenue per one employed persons or per one hour worked. However, the annualized average rate of growth (CAGR) of the indicator of labour productivity per one hour worked $(\mathrm{S} / \mathrm{T})$ was almost doubled compared to the indicator of labour productivity per one employed person. Second of them is the most frequently used in statistics. It increased up to 2013, while in 2014 there was observed a major reduction from 589.4 to 510.7 thousands PLN per one employed person, whereas in the subsequent years 2015-2017 one could admire a further (but slower) increase of this meter. The reasons of this tendency may be found, among others, in modernization of fixed assets (expressed using the index of capital equipment per one employed person - FA/L), which enables to produce and sell more goods and services with a lower increase in employment at the same time. On the other hand, labour productivity defined as sales revenue divided by annual labour costs remained at a similar level until 2013, and later on it decreased slightly. The 
annualized average rate of growth of S/Lc indicator between the years 2005 and 017 amounted to $-0.7 \%$. It may be the evidence of the increasing pressure on the increase of salaries simultaneously with the increased demand for labour resources after 2013 and may justify further investments in assets. CAGR of labour productivity, which is based on the added value, is noticeably higher than CAGR of labour productivity based on sales revenue. The difference in the value of this indicator results, among others, from the increase in labour costs which constitute one of the main categories making up the added value. Additionally, it is confirmed by the increase in CAGR of the VA/Lc by $0.6 \%$ and by the diversified but also relatively high CAGR for labour costs in PKD 2007 sections between 2005 and 2017 (table 2).

TABLE 2

The compound annual growth rate (CAGR) of labour productivity indicators, sales revenue (S), employment $(\mathrm{L})$ and labour costs $(\mathrm{Lc})$ between the years 2005 and 2017 (fixed prices, the previous year $=100$ )

\begin{tabular}{|l|c|c|c|c|c|c|c|c|c|c|}
\hline $\begin{array}{c}\text { PKD } \\
\text { section }\end{array}$ & $\mathbf{S} / \mathbf{Z}$ & $\mathbf{S} / \mathbf{T}$ & $\mathbf{S} / \mathbf{L c}$ & $\mathbf{A T} / \mathbf{Z}$ & $\mathbf{V A} / \mathbf{Z}^{*}$ & $\mathbf{V A} / \mathbf{T}^{*}$ & $\mathbf{V A} / \mathbf{L c} *$ & $\mathbf{S}$ & $\mathbf{Z}$ & $\mathbf{L c}$ \\
\hline $\mathrm{B}$ & 5.9 & 5.7 & 1.9 & 9.9 & 4.4 & 5.6 & 1.1 & 2.9 & -2.8 & 1.0 \\
\hline $\mathrm{C}$ & 3.7 & 5.3 & -0.4 & 5.1 & 5.5 & 6.9 & 1.4 & 6.4 & 2.6 & 6.8 \\
\hline $\mathrm{D}$ & 6.6 & 6.8 & 1.1 & 12.4 & 6.9 & 7.1 & 1.4 & 4.4 & -2.0 & 3.3 \\
\hline $\mathrm{E}$ & 3.7 & 6.2 & 0.8 & 5.1 & 6.0 & 8.6 & 3.1 & 8 & 4.1 & 7.1 \\
\hline $\mathrm{F}$ & 2.9 & 4.2 & 0.5 & -1.2 & 1.0 & 3.2 & -1.4 & 5.9 & 2.9 & 5.4 \\
\hline $\mathrm{G}$ & 1.8 & 3.3 & -1.8 & 2.7 & 1.8 & 3.9 & -1.9 & 6.4 & 4.5 & 8.4 \\
\hline $\mathrm{H}$ & 4.8 & 5.5 & 1.2 & 6.7 & 3.6 & 4.3 & 0.9 & 7.8 & 2.8 & 6.5 \\
\hline $\mathrm{I}$ & 1.1 & 6.7 & 0.1 & 0.9 & 0.3 & 6.4 & -0.8 & 9.0 & 7.8 & 8.9 \\
\hline $\mathrm{J}$ & -0.1 & 0.8 & -4.0 & 0.3 & 0.0 & 0.9 & -4.2 & 5.0 & 5.2 & 9.4 \\
\hline $\mathrm{L}$ & 2.2 & 4.8 & -0.6 & -2.7 & 1.7 & 4.4 & -1.3 & 4.5 & 2.2 & 5.1 \\
\hline $\mathrm{M}$ & -3.5 & 2.9 & -3.0 & 8.6 & -2.0 & 5.0 & -1.4 & 6.4 & 10.3 & 9.7 \\
\hline $\mathrm{N}$ & 6.6 & 9.0 & 0.0 & 5.8 & 4.9 & 6.8 & -1.9 & 13.7 & 6.7 & 13.7 \\
\hline
\end{tabular}

Explanations: * in sections: G, H, I, J, L and M the values were calculated for the years 20052016. The designations of the section PKD2007: B - mining and quarrying; C - manufacturing; D - electricity, gas, steam and air conditioning supply; E - water supply, sewage, waste management; F - construction; $\mathrm{G}$-wholesale and retail trade, vehicle repair; H transportation and storage; I - accommodation and food service activities; J - information and communication; L - real estate activities; $\mathrm{M}$ - professional, scientific and technical activity; $\mathrm{N}-$ administrative and support service activities.

Source: own elaboration on the basis: [Zatrudnienie..., 2018; Wyniki finansowe..., 2018; unpublished data from GUS]. 
Labour productivity measured at the level of PKD 2007 section can be characterized by noticeable but varied increase, as evidenced by the value of CAGR between 2005 and 2017 for the meters listed in the table 2 .

The high annualized average rate of growth of investment in modernizing of fixed assets in sections $\mathrm{B}$ and $\mathrm{D}$ in the analyzed period resulted in the reduction of employment on average by $2.0-2.8 \%$, while the annualized average rate of growth of sales revenue increased from 2.9 to almost $4.4 \%$. It was reflected in the CAGR of labour productivity per one employed person and per one hour worked around 6-6.8\%. In the dominating section in economy, i.e. manufacturing $(\mathrm{C})$, a relatively CAGR of labour productivity per one hour worked, which amounted to $5.3 \%$, was caused both by technical progress and by the improvement of the work organization. Considerably lower CAGR of labour productivity was noticed in most service sections that (due to the specific character of activity) require the involvement of a larger number of employees who are difficult to replace with machines, devices or IT systems.

The PKD 2007 sections are particularly diversified also in terms of the annualized average rate of growth of the labour costs. High CAGR of such costs simultaneously with the lower increase in sales revenue resulted in the reduction of labour productivity expressed using the relation between sales revenue and the labour costs. Similar (but slightly higher) levels of labour productivity can be obtained by measuring it using the relation between the added value and the labour input resources. Considerable differences between the meters of labour productivity, i.e. between high labour productivity based on the added value and relatively low labour productivity based on sales revenue may imply the involvement of relatively large external outlays, including the outsourcing of materials and services.

\section{Conclusions}

Labour productivity constitutes one of the basic meters of labour effectiveness, while its increase is an essential determinant of growth of a particular entity or economy. Depending on the aim and scope of research, the calculations are made using the set of meters based on two categories of effects, i.e. sales revenue and gross added value juxtaposed next to three categories of outlays, i.e. employment, hours worked and labour costs. Each of these indicators provides essential information serving the evaluation of labour resources, labour costs or the work organization. As the outlays of labour resources are interdependent, the usage of only one selected indicator of labour productivity may distort the image of the analyzed phenomenon. Therefore, the usage of a set of meters of labour productivity and the combination of them with the capital (technical) equipment appears to be justified.

The indicators used for the evaluation of labour productivity at the level of the enterprise sector or particular sections in the Polish economy showed considerable diversification in CAGR of labour productivity between the years 2005 and 2017 in 
the PKD 2007sections. The higher and increasing level of this productivity appears especially in the industrial activity (sections B, C, D and E) and in the service activity which made relatively large outlays on modernization of fixed assets in order to produce more and at lower cost at the same time and in order to reduce employment and control the increasing labour costs as well as to meet the increase in market demand. Therefore, the assessment of labour productivity ought to take into consideration the specific character of the conducted activity and the possibility of replacing labour resources with technical resources and with organizational solutions. However, it is difficult to measure these solutions because they are not directly reflected in financial data although they have a direct impact on changes in the values of such basic categories as the added value or sales revenue that make up the meters of productivity. Apart from time comparisons, the additional information on this phenomenon may be obtained by comparing its level with the adequate types of activity in other economies.

The most frequently used indicator of labour productivity per one employed person may confirm its increase. However, only after its supplementation with the remaining meters of labour productivity and with the indicator of capital (technical) equipment it is possible to have a more complex view at the analyzed phenomenon and achieve its proper evaluation. The analysis of the calculated meters of labour productivity and capital equipment showed that in general labour productivity per one employed person increased, but the relatively rapid increase of labour costs clearly corrected its level (e.g. in section N). Such findings mean that it is necessary to implement an incentive system of rewarding or modification type especially in the situations where there occurred a noticeable slowdown of labour productivity growth after 2013.

\section{References}

Analiz̨a ekonomiczna w przeedsiębiorstwie, 2013, Jerzemowska M. (red.), PWE, Warszawa. Balk M., 2014, Dissecting aggregate output and labour productivity change, "Journal of Productivity Analysis", vol. 42, iss. 1, pp. 35-43, DOI: 10.1007/s11123-013-0359-6.

Grześ A., 2017, Outsourcing w ksztattowaniu zatrudnienia, kosztów i produktywności pracy w przedsiębiorstwach, Wydawnictwo Uniwersytetu w Białymstoku, Białystok.

Handbook of Methods, 2012, BLS, https://www.bls.gov/opub/hom/pdf/msp-19970 714.pdf [date of entry: 05.04.2019].

Kosieradzka A., 2012, Zarzadzanie produktywnościa w przedsiębiorstwie, Wydawnictwo C.H. Beck, Warszawa.

OECD Compendium of Productivity Indicators 2018, 2018, OECD Publishing, Paris. Porter M.E., 1990, The Competitive Advantage of Nations, Free Press, New York. Potencjat pracy przedsięiorstwa, 2006, Gableta M. (red.), Wydawnictwo Akademii Ekonomicznej we Wrocławiu, Wrocław.

Potencjat pracy w przedsiebiorstwie, 1998, Gableta M. (red.), Wydawnictwo Akademii Ekonomicznej we Wrocławiu, Wrocław. 
Sargant Florence P., 1920, The Measurement of Labor Productivity, "Quarterly Publications of the American Statistical Association”, vol. 17, iss. 131, pp. 289-304.

Sierpińska M., Jachna T., 2004, Ocena przedsiebiorstwa wedtug standardón swiatonych, Wydawnictwo Naukowe PWN, Warszawa.

Solow R.W., 1967, Teoria kapitatu i stopy kapitatu, Państwowe Wydawnictwo Naukowe, Warszawa.

Sunderland F.O., Kane M.E., 1996, Measuring productivity on value basis, "Global Business and Organizational Excellence", vol. 15, iss. 4, pp. 57-76, DOI: 10.1002 /npr.4040150408.

Wyniki finansowe podmiotón gospodarczych w latach 2005-2017, 2018, GUS, Warszawa, http://stat.gov.pl/obszary-tematyczne/podmioty-gospodarcze-wyniki-finansowe /przedsiebiorstwa-niefinansowe/wyniki-finansowe-podmiotow-gospodarczych-ixii-2017,11,18.html [date of entry: 05.03.2019].

Zatrudnienie $i$ wynagrodzenie w gospodarce narodowej w 2005-2017, 2018, GUS, Warszawa, http://stat.gov.pl/obszary-tematyczne/rynek-pracy/pracujacy-zatrudnieni-wynagrodzenia-koszty-pracy/zatrudnienie-i-wynagrodzenia-w-gospodarce-narodowejw-pierwszym-kwartale-2018-r-,1,30.html [date of entry: 05.03.2019].

www 1, http://stat.gov.pl/wskazniki-makroekonomiczne [date of entry: 18.09. 2018]. 